$\begin{array}{r}\text { JOURNAL OF APPLIED SMART ELECTRICAL } \\ \text { NETWORK AND SYSTEMS (JASENS) } \\ \hline \text { ISAS }\end{array}$

\title{
Pembangkit Energi Listrik Hybrid Mini Menggunakan Tenaga Surya Sebagai Sumber Energi Alternatif
}

\author{
Arbi Nugraha $^{1}$, Pola Risma ${ }^{2}$, RD. Kusumanto ${ }^{3}$ \\ 1,2,3 Jurusan Teknik Elektro Program Studi Sarjana Terapan Teknik Elektro, Politeknik Negeri Sriwijaya \\ 12arbinugraha24@gmail.com, ${ }^{2}$ polarisma@polsri.ac.id, ${ }^{3}$ manto_6611@yahoo.co.id
}

\begin{abstract}
Hybrid system is the concept of combining two or more different energy sources to meet the needs of existing electricity loads. The advantage of this solar energy is that it is non-polluting, inexhaustible and can be used directly or indirectly and is energy for all time. In this study, a tool designed for hybrid electric energy generation using solar energy and wind energy. The solar panel used is $50 \mathrm{Wp}$ Polycrystalline type and The wind generator used is MY-1016 with an output power of 350 Watt. In this study, a system for monitoring the power generated electric energy generator using solar energy is needed which consists of components such as current sensors INA219, Arduino Mega 2560 and displayed in real time using the Internet of Things (IOT).
\end{abstract}

Keywords: Polycrsytalline 50 Wp Solar Panel, Arduino Mega 2560, INA219 Current Sensor, Internet of Things.

\begin{abstract}
Abstrak
Sistem Hybrid merupakan konsep pengabungan dua atau lebih sumber energi yang berbeda untuk memenuhi kebutuhan beban listrik yang ada. Keunggulan dari energi matahari ini adalah tidak bersifat polutif, berlimpah, tidak pernah habis dan dapat dimanfaatkan secara langsung maupun tidak langsung dan merupakan energi sepanjang masa. Pada penelitian ini dirancang alat untuk pembangkit energi listrik menggunakan energi surya dan energi angin. Panel surya yang di pakai berjenis Polycrystalline sebesar $50 \mathrm{Wp}$ dan generator angin yang dipakai adalah MY-1016 dengan daya keluaranya 350 Watt. Dalam penelitian ini dibutuhkan sebuah sistem untuk monitoring daya yang dihasilkan pada pembangkit energi listrik hybrid menggunakan energi surya dan energi angin yang terdiri dari komponen seperti sensor arus INA219, Arduino Mega 2560 dan ditampilkan secara real time menggunakan Internet Of Things (IOT).
\end{abstract}

Kata kunci: Panel Surya Polycrystalline 50 Wp, Arduino Mega 2560, Sensor Arus INA219, Internet Of Things.

Diterima Redaksi : 08-07-2021 | Selesai Revisi : 20-12-2021 | Diterbitkan Online : 31-12-2021

\section{Pendahuluan}

Sistem Hybrid merupakan konsep penggabungan dua atau lebih sumber energi yang berbeda untuk memenuhi kebutuhan beban listrik yang ada, sehingga hal ini diharapkan dapat mengatasi penggunaan energi apabila supply energi yang lain bermasalah. Kondisi lokasi dan situasi pada pembangkit energi listrik yang tidak dapat diprediksi memungkinkan pemantauan dari parameter-parameter pembangkit dan beban listrik dilakukan melalui jarak jauh dengan memanfaatkan suatu komunikasi internet yang mengimplementasikan [1]-[5].

Pembangkit listrik hybrid dengan menggunakan energi surya ini menggunakan panel surya berjenis polycrystalline dengan daya $50 \mathrm{Wp}$ karena pembangkit ini digunakan untuk menghidupkan penerangan dengan daya yang relative rendah. Prototype hybrid yang akan kami buat ini bertujuan untuk mengetahui berapa daya optimal yang akan dihasilkan.

Digunakannya panel surya berjenis polycrystalline ini karena mempunyai efisiensi yang sedikit lebih rendah daripada panel surya jenis monocrystalline. Pembangkit energi listrik ini sangat efektif digunakan, karena tidak merusak lingkungan dan sangat cocok untuk meminimalisir peningkatan beban daya yang diserap [6]-[10].

Pada penelitian yang berjudul pengaruh material monocrystalline dan polycrystalline terhadap karakteristik sel surya 20 WP dengan tracking dua sumbu masih menggunakan solarr cell berjenis 
monocrystalline (2017) [11]-[16]. Pada alat yang kami gunakan adalah solar cell berjenis polycrystalline dengan tingkat kinerja yang stabil saat peningkatan suhu yang berubah-ubah.

Pada penelitian yang berjudul pemanfaatan sistem pembangkit hybrid dengan kendali supply beban (2018) [12][18], belum menggunakan sistem internet of things. Pada pembangkit hybrid yang kami buat sudah menggunakan sistem internet of things.

Pada penelitian yang berjudul pembangkit listrik hybrid tenaga surya dan angin energi fosil di sumatera (2019) [2], sistem monitoring masih dilakukan dari jarak dekat. Pada pembangkit listrik yang kami buat sudah bisa melakukan monitoring daya yang dihasilkan pada pembangkit dari jarak jauh [17]-[24].

Pada penelitian yang berjudul rancang bangun pembangkit hybrid tenaga angin dan surya dengan penggerak otomatis pada panel surya (2020) [13], sistem kontrol masih dilakukan dari jarak dekat. Pada pembangkit listrik yang kami buat sudah bisa melakukan sistem kontrol pada pembangkit dari jarak jauh.

Paper ini membahas tentang pembangkit listrik energi surya yang terhubung pada sistem hybrid mini. Energi surya yang dipakai pada penelitian ini berjenis polycrystalline dengan menggunakan simulasi SAM. Sistem panel surya ini dilengkapi dengan sensor INA219 sebagai input bagi pembangkit listrik yang dimonitoring daya yang dihasilkan pembangkit listrik secara Internet Of Things (IOT) dengan menggunakan aplikasi Blynk.

\section{Metode Penelitian}

\subsection{Panel Surya}

Panel Surya adalah modul surya yang terbuat dari bahan semikonduktor. Bahan semikonduktor merupakan bahan semi logam yang memiliki partikel yang disebut elektron-proton. Panel surya mampu menyerap sinar matahari yang mengandung gelombang elektromagnetik yang dapat diubah menjadi energi listrik. Panel surya yang digunakan berjenis polycrystalline $50 \mathrm{Wp}$ karena panel surya jenis ini berbahan multi-kristal. Digunakannya Panel surya polycrystalline ini karena mempunyai efisiensi dan output daya yang stabil.

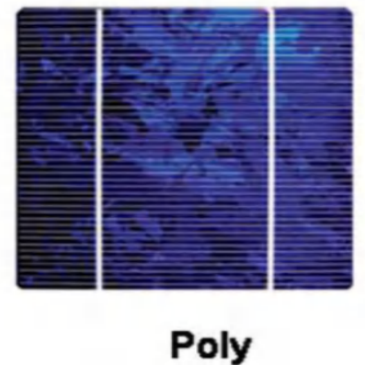

Gambar 1. Panel Surya Polycrystalline [3] Sumber: U. Hasanudin, 2017

\subsection{Solar Charge Controller}

Solar charge controller adalah charger baterai yang disuplai dari panel surya. Perangkat elektronik ini berfungsi untuk mengatur arus dari panel surya ke dalam baterai. Perangkat ini memiliki fitur yang lengkap dan pengoperasian yang mudah dengan satu potensiometer untuk pengaturan tegangan

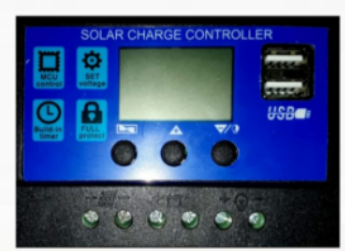

Gambar 2. Solar Charge Controller

\subsection{Mikrokontroller Arduino Mega 2560}

Mikrokontroler adalah sebuah sistem komputer yang seluruh atau sebagian besar elemennya dikemas dalam satu chip IC, sehingga sering disebut dengan single chip mikrokomputer.

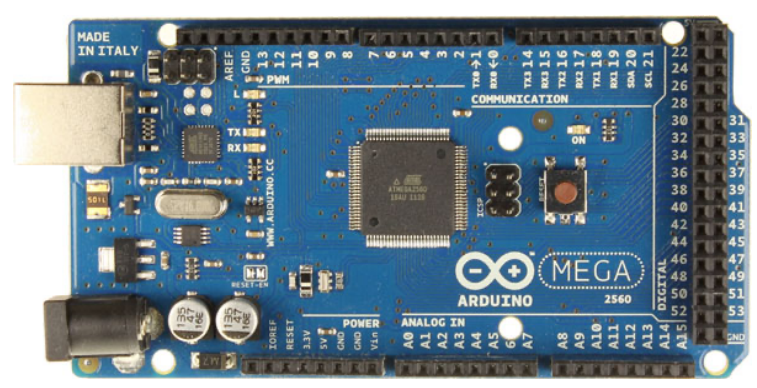

Gambar 3. Arduino Mega 2560 [4] Sumber: A Haripurna 2013 
Arduino Mega 2560 adalah board mikrokontroler yang 2.6. Relay

berbasis pada ATmega2560. Memiliki 54 pin input /

output digital, 16 input analog, 4 UART (port serial Relay adalah saklar yang dioperasikan secara listrik perangkat keras), osilator kristal $16 \mathrm{MHz}$, koneksi dan merupakan komponen electromechanical yang USB, header ICSP, dan tombol reset. Berisi semua terdiri dari 2 bagian utama yakni coil dan mekanikal. yang dibutuhkan untuk mendukung mikrokontroler [5]. Fungsi relay disini untuk menghidupkan dan

\subsection{Sensor Arus INA219} mematikan panel surya dan beban yang mana

Sensor arus yang digunakan berupa modul sensor arus INA219 yang memiliki kegunaan untuk mendeteksi besar arus yang mengalir lewat blok terminal [6]. Sensor INA219 merupakan modul yang dapat memonitoring tegangan dan arus pada suatu rangkaian listrik. INA 219 didukung dengan interface I2C atau SMBUS-COMPATIBLE dimana peralatan ini mampu memonitoring tegangan shunt dan suplai tegangan bus, dengan konversi program times dan filtering. [7]. INA 219 memiliki sebuah amplifier input maksimum adalah $\pm 320 \mathrm{mV}$ ini berarti dapat mengukur arus hingga $\pm 3,2 \mathrm{~A}$. dikoneksikan dengan sistem Internet Of Things.

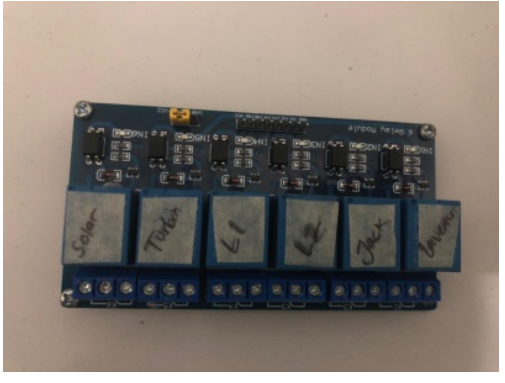

Gambar 6. Relay

\subsection{Inverter}

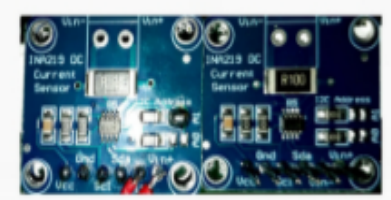

Gambar 4. Sensor Arus INA219

\subsection{Baterai}

Baterai adalah alat elektro kimia yang dibuat untuk mensuplai energi listrik ke komponen kelistrikan. Baterai menyimpan listrik dalam bentuk energi kimia, yang dikeluarkannya bila diperlukan dan mensuplai ke masing-masing sistem kelistrikan atau alat yang memerlukannya. Pada rangkaian pembangkit listrik hybrid tenaga angin dan matahari ini menggunakan baterai GS Hybrid NS60 12V 7,5 AH.

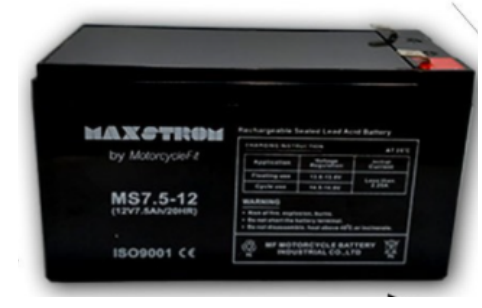

Gambar 5. Baterai

Inverter adalah suatu rangkaian atau perangkat elektronika yang dapat mengubah arus listrik searah (DC) ke arus listrik bolak-balik (AC) pada tegangan dan frekuensi yang dibutuhkan sesuai dengan perancangan rangkaiannya. Sumber-sumber arus listrik searah atau arus DC yang merupakan input dari power inverter tersebut dapat berupa baterai, aki, maupun sel surya. Pada rangkaian pembangkit listrik hybrid tenaga angina dan matahari ini menggunakan power inverter dc to ac $12 \mathrm{~V}$ to $220 \mathrm{~V}$.

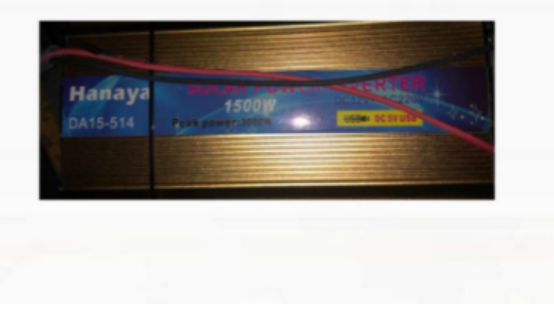

Gambar 7. Inverter

\subsection{Blok Diagram}

Pada rangkaian monitoring menggunakan mikrokontroler Arduino Mega berbasis wifi sehingga memungkinkan perangkat yang akan dirancang dapat terkoneksi ke internet, rangkaian monitoring ini juga menggunakan Sensor INA219 sebagai pembacaan Tegangan dan Arus dari Solar dan Battery, Selain itu rangkaian ini juga dipasang sensor tegangan dan arus AC untuk mengukur tegangan dan arus beban pada saat beban aktif, beban pada rangkaian ini menggunakan Lampu LED AC yang mana terhubung pada module Journal of Applied Smart Electrical Network and Systems (JASENS) 
relay sehingga lampu dapat dihidup dan matikan menggunakan smartphone melalui aplikasi yang telah dirancang.

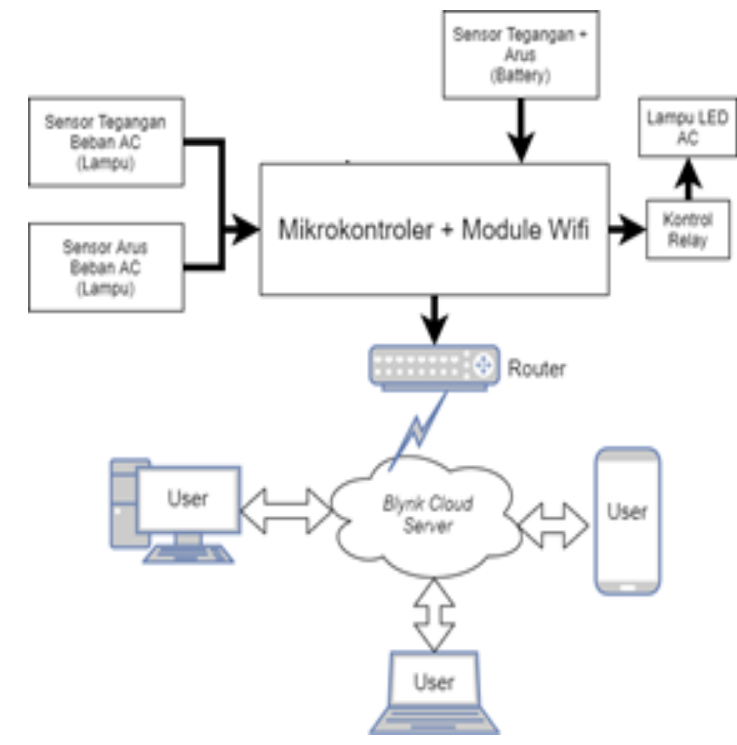

Gambar 8. Blok Diagram Pembangkit Energi Listrik Menggunakan Energi Surya

Proses pengiriman data dari perangkat monitoring

menggunakan server blynk sehingga aplikasi dapat 2.10. Desain Software mengakses semua data secara online dan realtime. Aplikasi yang telah dirancang dapat digunakan pada smartphone tipe android maupun ios serta dapat diinstall pada laptop maupun komputer.

\subsection{FlowChart Rangkaian}

Ketika perangkat diaktifkan seluruh sensor akan melakukan inisialisasi agar dapat diakses oleh mikrokontroler, selanjutnya mikrokontroler mencari koneksi internet dan setelah terkoneksi, seluruh data hasil pembacaan dikirimkan ke server blynk agar dapat ditampilkan ke aplikasi yang telah kita rancang, apabila hasil pembacaan tengan dan sensor terdapat anomali (tidak normal) maka akan muncul notifikasi pada aplikasi bahwa terdapat tegangan dan arus yang tidak normal sesuai dengan settingan yang diinput pada mikrokontroller yang kita gunakan.

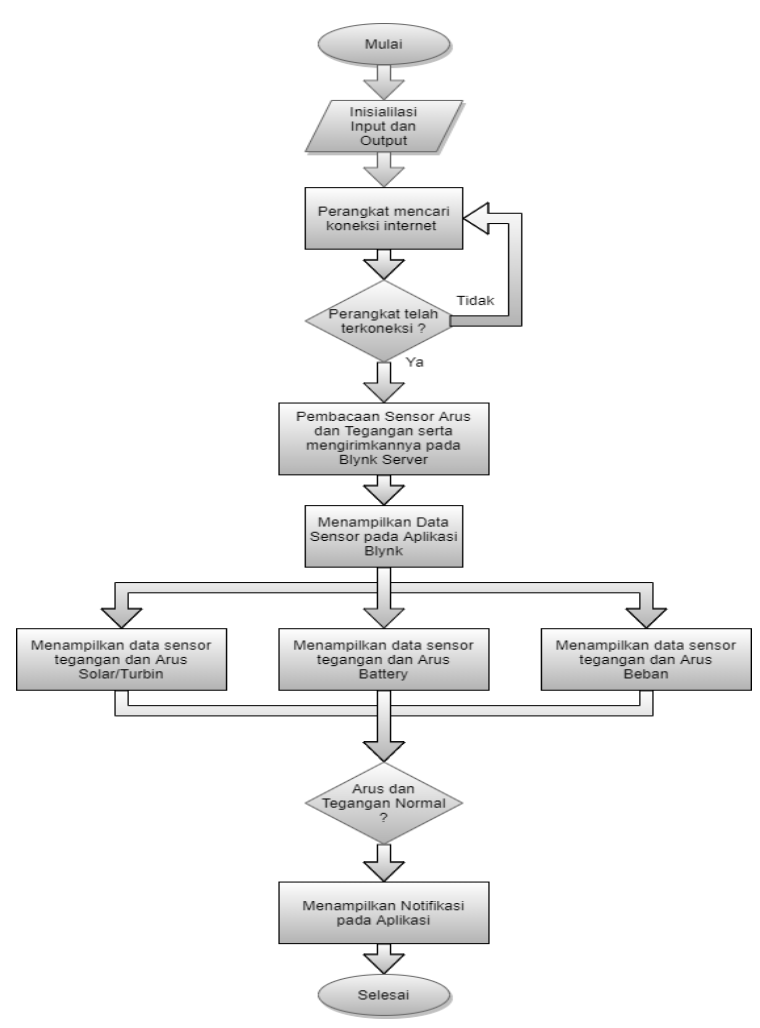

Gambar 9. Flowchart Pembangkit Energi Listrik Menggunakan Energi Surya

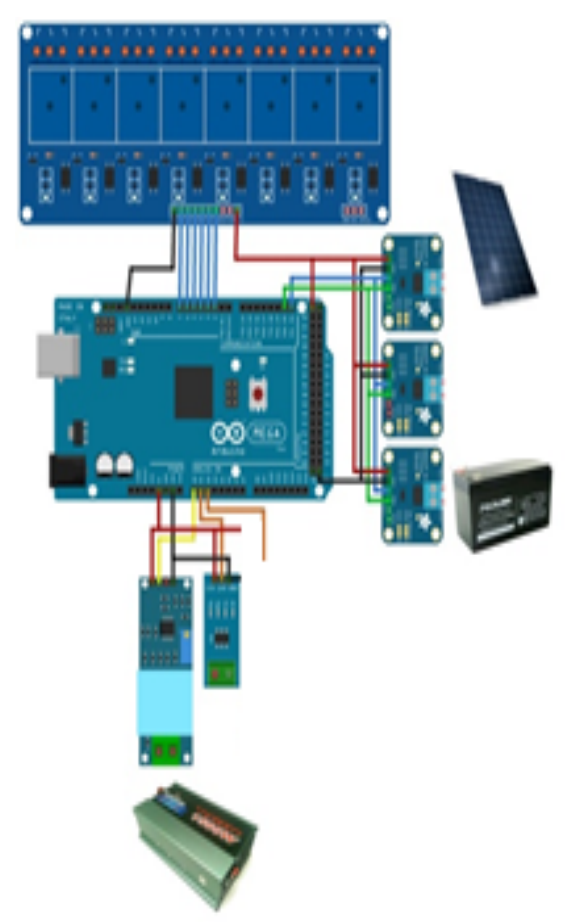

Gambar 10. Desain Software 


\subsection{Internet Of Things}
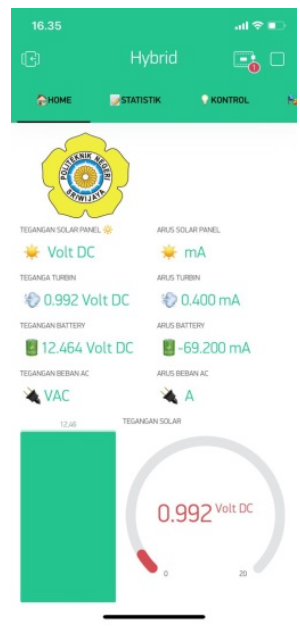

Gambar 11. Internet Of Things

Internet of Things atau dikenal juga dengan singkatan IoT, merupakan sebuah konsep yang bertujuan untuk memperluas manfaat dari konektivitas internet yang tersambung secara terus menerus yang memungkinkan kita untuk menghubungkan mesin, peralatan, dan benda fisik lainnya dengan sensor jaringan dan aktuator untuk memperoleh data dan mengelola kinerjanya sendiri, sehingga memungkinkan mesin untuk berkolaborasi dan bahkan bertindak berdasarkan informasi baru yang diperoleh secara independen.

Prinsip kerja Internet of Things yaitu dengan memanfaatkan sebuah pemrograman yang dimana tiaptiap perintah itu menghasilkan sebuah interaksi antara sesama mesin yang terhubung secara otomatis tanpa campur tangan manusia dan dalam jarak berapa pun.Internetlah yang menjadi penghubung di antara kedua interaksi mesin tersebut, sementara manusia hanya bertugas sebagai pengatur dan pengawas bekerjanya alat tersebut secara langsung. Internet of Things akan digunakan untuk memonitoring berapa daya yang dihasilkan pada pembangkit listrik tenaga surya dengan menggunakan aplikasi Blynk [8].

\section{Hasil Dan Pembahasan}

\subsection{Kinerja Solar Cell Menggunakan Aplikasi SAM}

Setelah dilakukan simulasi menggunakan aplikasi SAM (System Advisor Model) dengan menggunakan solar cell $50 \mathrm{Wp}$ didapatkan grafik berupa energi yang dihasilkan dalam waktu kurun dari 1 tahun. Pada grafik ini juga kita mengtahui berapa daya maksimal yang dihasilkan setiap bulanya.

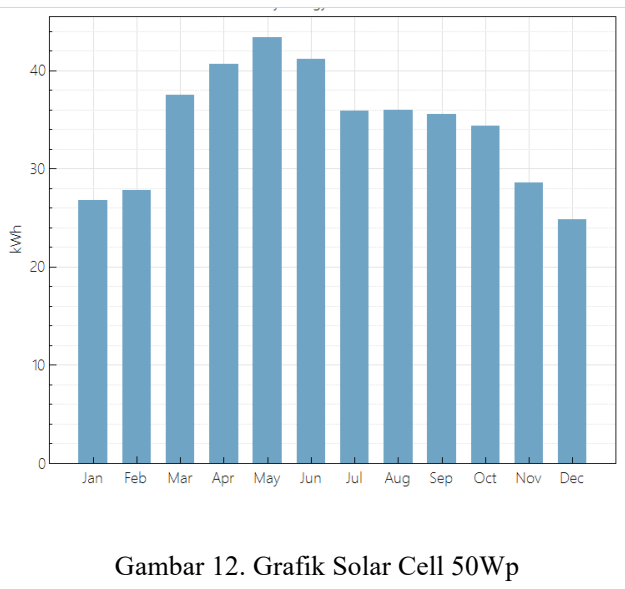

Pada Gambar 12. dapat kita lihat kinerja pembangkit listrik selama 1 tahun jika kita menggunakan solar cell yang memiliki output 50Wp. Selama 1 tahun dapat menghasilkan energi sebesar $413 \mathrm{kWh}$.

\begin{tabular}{|ll|}
\hline Metric & Value \\
\hline Annual energy (year 1) & $413 \mathrm{kWh}$ \\
Capacity factor (year 1) & $14.4 \%$ \\
Energy yield (year 1) & $1,261 \mathrm{kWh} / \mathrm{kW}$ \\
Performance ratio (year 1) & 0.53 \\
Levelized COE (nominal) & $17.93 \varangle / \mathrm{kWh}$ \\
Levelized COE (real) & $14.32 థ / \mathrm{kWh}$ \\
Electricity bill without system (year 1$)$ & $\$ 1,514$ \\
Electricity bill with system (year 1) & $\$ 1,472$ \\
Net savings with system (year 1) & $\$ 42$ \\
Net present value & $\$-214$ \\
Simple payback period & 17.0 years \\
Discounted payback period & $\mathrm{NaN}$ \\
Net capital cost & $\$ 822$ \\
Equity & $\$ 0$ \\
Debt & $\$ 822$ \\
\hline
\end{tabular}

Gambar 13. Data Akhir Dari Solar Cell 50Wp

Pada Gambar 13. dapat kita lihat loss energy pada pembangkit listrik hybrid menggunakan solar cell 50 Wp pertahunnya, seperti yang dilihat lost energy terbanyak selama 1 tahun disebabkan oleh inverter. 


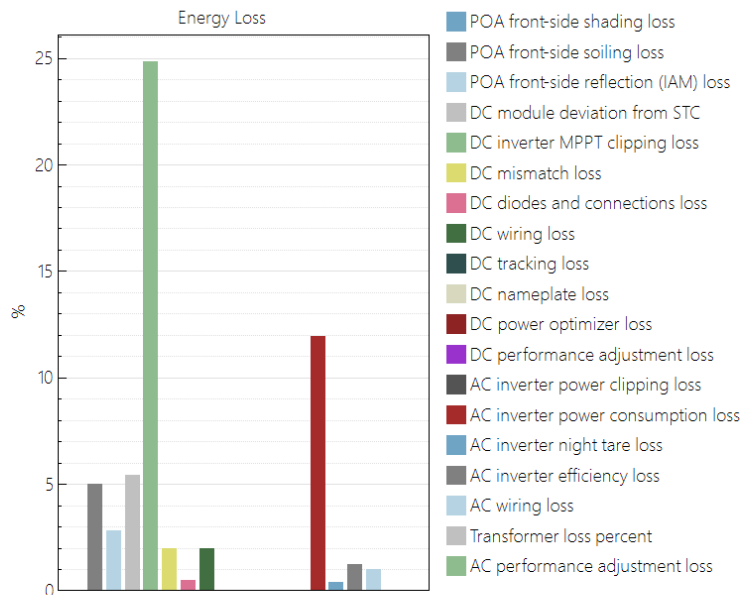

Gambar 14. Lost Energy Solar Cell 50Wp

\section{Kesimpulan}

Dari penelitian yang telah dilakukan, Pembangkit energi listrik hybrid menggunakan solar cell berjenis polycrystalline yang memiliki output maksimal $50 \mathrm{Wp}$ sangat efektif dan efisien. Dapat dilihat dari hasil data yang didapatkan menggunakan software SAM yang dimana energi listrik yang didapatkan untuk 1 tahunya mencapai $413 \mathrm{kWh}$. Pembangkit energi listrik hybrid menggunakan solar cell sebagai sumber energi alternative adalah sumber energi yang mudah didapatkan, ramah lingkungan, sesuai untuk berbagai macam kondisi geografis, Instalasi, pengoperasian dan perawatannya yang mudah.

\section{Daftar Rujukan}

[1] Maiti and Bidinger, "Wind and Solar power system," $J$ Chem. Inf. Model., 53(9), pp. 1689-1699, 1981.

[2] Tharoz. P and Andriana. M, "Pembangkit Listrik Hybrid Tenaga Surya Dan Angin Energi Fosil Di Sumatera,” pp. 141-144, 2019.

[3] Mubarak. H. F., "Hybrid Wind-Solar Electric Power System," 1(084084), p. 2, 2013.

[4] Haripurna A., "Arduino Mega2560," (2010), pp. 5-48, 2013.

[5] Maulana, “Arduino Mega 2560 Datasheet," Power, p. 3, 2015, [Online]. Available: http://www.robotshop.com/content/PDF/ArduinoMega256 0Datasheet.pdf.

[6] Monda. H. T., Feriyonika. F., and Rudati. P. S., "Sistem Pengukuran Daya pada Sensor Node Wireless Sensor [9] Network," Pros. Ind. Res. Work. Natl. Semin., 9, pp. 28-31, 2018.

[7] PROJECT. A, "Sensor INA219," 2017. https://www.nyebarilmu.com/cara-mengukur-teganganarus-dc-menggunakan-sensor-ina219/.

[8] Winasis. W., Nugraha. A. W. W., Rosyadi. I., an Nugroho. F. S. T., "Desain Sistem Monitoring Sistem Photovoltaic Berbasis Internet of Things (IoT)," J. Nas. Tek. Elektro dan Teknol. Inf., 5(4), pp. 328-333, 2016, doi: [10] 10.22146/jnteti.v5i4.281.

[9] SOON CHING CHUN, "DEVELOPMENT OF A HYBRID SOLAR WIND TURBINE FOR SUSTAINABLE ENERGY STORAGE,” no. July, p. 2015, 2015, [Online]. Available: http://weekly.cnbnews.com/news/article.html?no=124000.

[10] Adejumobi. I. A., Oyagbinrin. S. G., Akinboro. F.G., Olajide. M. B., and State. O., "Hybrid Solar and Wind Power: an Essential for Information Communication Technology Infrastructure and People in Rural Communities," Int. J. Res. Rev. Appl. Sci., 9. Oct, pp. 130138, 2011, [Online]. Available: https://pdfs.semanticscholar.org/bf99/c332bcdcd9e2fa23a8 75c819b1500e046361.pdf.

[11] Richard M Napitupulu, Sutan Simanjuntak, and Swardi Sibarani, 2017. "PENGARUH MATERIAL MONOKRISTAL DAN POLIKRISTAL TERHADAP KARAKTERISTIK SEL SURYA 20 WP DENGAN TRACKINGSISTEM DUA SUMBU - Swardi Sibarani,".

[12] H. Abdillah, A. N. Afandi, and ..., 2018. "Pemanfaatan Sistem Pembangkit Hybrid Dengan Kendali Supply Beban," Pros. Semin. ..., 02(01), pp. 59-64. [Online]. Available:

https://prosiding.polinema.ac.id/sngbr/index.php/sntet/arti cle/view/17

[13] Hidayanti. D. and Dewangga. G., "Rancang Bangun Pembangkit Hybrid Tenaga Angin dan Surya dengan Penggerak Otomatis pada Panel Surya," Eksergi, 15(3), p. 93, 2020, doi: 10.32497/eksergi.v15i3.1784.

[14] Hasanudin. U., "Hybrid Solar and wind," Hybrid Sol. Wind, 4, pp. 9-15, 2017.

[1] IRENA, Renewable Energy Prospects: Indonesia, a REmap analysis, International Renewable Energy Agency (IRENA), Abu Dhabi, 2017, www.irena.org/remap.

2] DEN, "Outlook Energy Indonesia 2019," Secretariat General National Energy Council, ISSN 2527-3000.

[3] Wardhana. A. T., Taqwa. A. and Dewi. T., "Design of Mini Horizontal Wind Turbine for Low Wind Speed Area," In Proceeding of Journal of Physics: Conference Series 347(1), p. 01202, 2019.

[4] Yuliandi. R. B., Dewi. T., and Rusdianasari, "Comparison of Blade Dimension Design of a Vertical Wind Turbine Applied in Low Wind Speed," In proceeding of E3S Web of Conferences EDP Sciences, 68, p. 01001, 2018.

5] Hanafiah. B., Taqwa. A., RD Kusumanto, and Dewi. T., "Synchronization and Application of IoT for on Grid Hybrid PV-Wind System," In Proceeding of 2018 International Conference on Applied Science and Technology (iCAST) IEEE, p. 617-621, 2018.

[6] Sarwono, Dewi. T, and RD Kusumanto, "Geographical Location Effects on PV Panel Output - Comparison Between Highland and Lowland Installation in South Sumatra, Indonesia," Technology Reports of Kansai University, 63(02), pp. 7229-7243, 2021. ISSN: 04532198.

[7] Sasmanto. A. A., Dewi. T., and Rusdianasari, "Eligibility Study on Floating Solar Panel Installation over Brackish Water in Sungsang, South Sumatra," EMITTER International Journal of Engineering Technology, 8(1), 2020.

[8] Junianto. B., Dewi. T., and Sitompul. C. R.,"Development and Feasibility Analysis of Floating Solar Panel Application in Palembang, South Sumatra Journal of Physics: Conf. Series 3nd Forum in Research, Science, and Technology Palembang, Indonesia, 2020.

9] Yudha. H. M., Dewi. T., Risma. P., and Oktarina. Y., "Life Cycle Analysis for the Feasibility of Photovoltaic System Application in Indonesia," in Proceeding International Conference on Science, Infrastructure Technology and Regional Development (ICoSITeR) 2017 'Energy Security for Enhancing National Competitiveness" 25-26 August 2017, South Lampung, Indonesia, IOP Conference Series: Earth and Environmental Science 124 012005, 2018. doi :10.1088/17551315/124/1/012005.

10] Arissetyadhi. I., Dewi. T., and RD Kusumanto, "Experimental Study on The Effect of Arches Setting on Semi-Flexible Monocrystalline Solar Panels, "Kinetik: Game Technology, Information System, Computer Network, Computing, Electronics, and Control. KINETIK 5(2), pp. 111-118, 2020.

Journal of Applied Smart Electrical Network and Systems (JASENS) 
[11] Harahap. H. A., Dewi. T., and Rusdianasari, "Automatic Cooling System for Efficiency and Output Enhancement of a PV System Application in Palembang, Indonesia," in 2nd Forum in Research, Science, and Technology, IOP Conf. Series: Journal of Physics: Conf. Series 1167 012027, 2019. doi:10.1088/1742-6596/1167/1/012027.

[12] Setiawan. F., Dewi. T., and Yusi. S., "Sea Salt Deposition Effect on Output and Efficiency Losses of the Photovoltaic System; a case study in Palembang, Indonesia," in Proceeding of Journal of Physics: Conf., 1167, p 012027, 2019.

[13] Junaedi. K, Dewi. T, and Yusi. M. S, 2021 "The Potential Overview of PV System Installation at the Quarry Open Pit Mine PT. Bukit Asam, Tbk Tanjung Enim," Kinetik: Game Technology, Information System, Computer Network, Computing, Electronics, and Control, 5(1), pp. 41-50,. https://doi.org/10.22219/kinetik.v6i1.1148.

[14] Dewi. T, Risma. P, and Oktarina. Y, 2018,2019, “A Review of Factors Affecting the Efficiency and Output of a PV system Applied in Tropical Climate," in IOP Conference Series: Earth and Environmental Science 258012039 ICoSITer. doi:10.1088/1755-1315/258/1/012039.

[15] Edward. A, Dewi. T, and Rusdianasari, 2019, "The effectiveness of Solar Tracker Use on Solar Panels to The Output of The Generated Electricity Power IOP Conference Series," in Proceeding of Earth and Environmental Science, 347(1), p. 012130.

[16] Hamdi. BRD. M, Dewi. T, and Rusdianasari, 2019. "Performance Comparison of 3 Kwp Solar Panels Between Fixed and Sun Tracking in Palembang-Indonesia," In Proceeding of IOP Conference Series: Earth and Environmental Science, 347(1). p. 012131,

[17] Zhafarina. I. N, Dewi. T, and Rusdianasari, 2018. "Analysis of Maximum Power Reduction Efficiency of Photovoltaic System at PT. Pertamina (Persero) RU III Plaju," VOLT: Jurnal Ilmiah Pendidikan Teknik Elektro, 3(1), pp.19-25.

[18] Dewi. T, Risma. P, Oktarina. Y, Roseno. M. T, Yudha,. M. H. Handayani. A. S, and Wijanarko. Y, 2016“A Survey on Solar Cell; The Role of Solar Cell in Robotics and Robotic Application in Solar Cell industry," in Proceeding Forum in Research, Science, and Technology (FIRST),. Retrieved from http://eprints.polsri.ac.id/3576/3/C4.pdf.

[19] Dewi. T, Risma. P, Oktarina. Y, Taqwa. A, Rusdiansari, and Renaldi. H. "Experimental Analysis on Solar Powered Mobile Robot as the Prototype for Environmentally Friendly Automated Transportation," presented in International Conference on Applied Science and Technology (iCAST on Engineering Science) Bali, Indonesia, of Physics: Conference Series, Vol. 1450.

[20] Putra. P. P, Dewi. T, Rusdianasari, "MPPT Implementation for Solar-powered Watering System Performance Enhancement,"
Technology Reports of Kansai University, 63(1), pp. 69196931, 2021. ISSN: 04532198.

[21] Eshra. N . G, and Salem. M. G, 2020 "Solar Energy Application in Drainage Pumping Stations to Save Water and Reducing CO2 Emission," Energy Reports, Vol. 6, Supplement 6, pp. 354-366, https://doi.org/10.1016/j.egyr.2020.08.056.

22] Imjai.T ,Thinsurat. K, Ditthakit. P, Wipulanusat. W, Setkit. M, and Garcia. R, 2020. "Performance Study of an Integrated Solar Water Supply System for Isolated Agricultural Areas in Thailand: A Case-Study of the Royal Initiative Project," Water, Vol. 12, p. 2438

[23] Korpale. V. S, Kokate. D. H, and Deshmukh. S. P, 2016. "Performance Assessment of Solar Agricultural Water Pumping System," Energy Procedia, Vol. 90, pp. 518-524. https://doi.org/10.1016/i.egypro.2016.11.219.

[24] Elrefai. M, Hamdy. R. A, ElZawawi. A, and Hamad. M. S, 2016. "Design and Performance Evaluation of a Solar Water Pumping System: a Case Study," 2016 Eighteenth International Middle East Power Systems Conference (MEPCON), Cairo. pp. 914-920, doi: 10.1109/MEPCON.2016.7837005.

[25] Aroudam. A. BA. A, Chighali. O. E, Hamdoun. O, and Mohamed. M. L, 2018 "Performance Optimization of the PV Pumping System," presented in 11th International Conference Interdisciplinarity in Engineering, INTER-ENG 2017, 5-6 October 2017, Tirgu-Mures, Romania, Procedia Manufacturing, Vol. 22, pp. https://doi.org/10.1016/j.promfg.2018.03.112 